\title{
Factors of Critical Spatial Thinking for a Geography Metacognition Assessment in Indonesian Senior High Schools
}

Muhammad NURSA'BAN'

Yogyakarta State University, Yogyakarta, INDONESIA
Kumaidi KUMAIDI²

Muhammadiyah University of Surakarta, Surakarta, INDONESIA

\section{Mukminan MUKMINAN ${ }^{3}$}

Yogyakarta State University, Yogyakarta, INDONESIA

'Corresponding author: Muhammad Nursa'ban, Department of Geography Education, Faculty of Social Sciences, Yogyakarta State University, Yogyakarta, Indonesia, m_nursaban [at] uny.ac.id. ORCID: 0000-0003-3870-9085

2 Dept. of Psychology, Muhammadiyah University of Surakarta, Indonesia, kum231 [at] ums.ac.id. ORCID: 0000-0002-2736-6139

${ }^{3}$ Department of Geography Education, Faculty of Social Sciences, Yogyakarta State University, Yogyakarta, Indonesia, mukminan [at] uny.ac.id. ORCID: 0000-0003-1140-7423

\section{Abstract}

Factors of Critical Spatial Thinking for a geography metacognition assessment are a moot point among experts and practitioners. This study aims to develop an understanding about such factors by using a structural equation model to generate a comprehensive and accurate assessment instrument for metacognition in geography. The study is a research and development project for a Thesis. The current research involves 595 participants, consisting of experts and practitioners from eight representative Senior High Schools in Indonesia. The study occurred between August 2017 and February 2019. The results from a confirmatory factor analysis generated 15 indicators for three dimensions of critical spatial thinking. The three dimensions are concept comprehension, concept application, and creativity in producing ideas; and they are used to generate an assessment for metacognition in geography. The indicators involve concept application, location, distance, approach, equation, disaster mitigation, concept map, interaction, map instrument, aura, region, hierarchy, pattern, spatial association, and inquiry. The factors were assessed by nine experts and obtained 0.85 on the Aiken validity index. A chi-square of 330.47 , $d f=90, p$-value $=0.000$, and Root Mean Square Error of Approximation $=0.071, t=4.78$, and GFI $=1.96$ in the significance level of $5 \%$, proves the items fulfil both the analysis and construct dimensions, and also have a significant influence on the dimensions and factors of metacognition.

\section{Keywords}

Spatial Critical Thinking, Geography Education, Assessment, Metacognition 
Geography is an important subject in Indonesian Senior High School's (SHS). SHS is a formal level of secondary education for 15-18 years old students. The curriculum for geographic competencies taught at the Middle School level is essentially the study of critical spatial thinking, which occurs as a holistic approach to learning by developing understanding and skills about spatial representation. Critical spatial thinking is a way of interpreting geographical phenomena, expressed in writing and more abstract forms, to describe the dynamics of integration and interdependence of the spatial environment. Various concepts of spatial thinking provide boundaries which intersect with representations of critical spatial thinking in geographic curricula (Lee \& Bednarzd, 2012; Jo \& Bednarz, 2010; Gersmehl \& Gersmehl, 2007; Bednarz \& Bednarz, 2008; Golledge et al., 2008; Goodchild \& Janelle, 2010). Critical thinking is a form of multiple intelligence and requires many types of information to make decisions (Branch, 2014; Gold et al., 2018; Bednarz et al., 2013; Uttal et al., 2012, 2013, \& Gardner, 2006). Branch (2014) added that 'spatial thinking' is a critical thought process that should be owned by many stakeholders in education such as teachers.

The Indonesian geography curriculum aims to equip learners with the ability to discover and understand the spatial phenomena of earth. The competencies of geographical learning are formulated from the perspective of understanding the relationship and interactions between human and environmental systems. Hanifah et.al. (2019) states that a geographical perspective of the physical environment and society is viewed from the lenses of spatial integration and spatial interdependences. However, students are frequently worried about their levels of geographical awareness (Swasono, 2014; Prasetyo, 2013). Students mostly lack knowledge about the Indonesian identities and spaces such as state boundaries, or the names of big cities and mountains. Such a situation implicitly indicates that the students' repertoire of thinking skills in geography are still poor since they do not think critically. To overcome this problem, approaching the spatially focused critical thinking skills through an analysis of similarities and differences between people, places and environments can enrich student knowledge and understanding. In so doing, it can also lead to the development of understanding about past processes to illuminate the present and to think about the future. Such an achievement in geographical learning may foster the development of spatial thinking and critical thinking skills. Kozikoğlu (2019) states that critical thinking has a relationship with metacognitive skills, problem solving skills, and perceptions of academic self-efficacy.

The analysis focuses on the spatial thinking aspects of the geography standards from the National Research Council (2006) in the United State of America; specifically, from essential Element I about how to analyze the spatial organization of people, places, and environments across Earth's surface. Spatial thinking represents the ability to transform knowledge by manipulating, reconstructing, and navigating physical objects to achieve academic and intellectual success (Gold et.al, 2018; Newcombe \& Shipley, 2015; Utall \& Newcombe, 2013). Geographical thinking extrapolates beyond spatial thinking to include recognition and elaboration of the relationship that exists between spatial concepts, and about the relationship between theory and generalization. Bonnet (2008) clarifies the meaning of spatial analysis in the field of geography 
to be when phenomena are represented by the physiographic conditions of landscapes and human activities by emphasizing the existence of integrated spatial interconnections. In alignment with this view, Creswell (2006) states that spatial construction in geography does not eliminate the instilled values and meaning. Furthermore, geography examines the organization of location and space for human activity on Earth (Lambert \& Morgan, 2010). Also, spatial and ecological perspectives are key perspectives for understanding and studying geography (Heffron, 2012). In support of such ideas from the experts, Jo \& Bednarz (2014) suggest that the integration of spatial thinking skills in to the teaching and learning of geography will assist the students to achieve the learning objectives of the course.

Therefore, learning about geography will exemplify and develop an understanding about changes occurring in the natural and human environment, especially through the idea of development that is applied to a country or region. Such an opinion can be reduced to a general understanding that geography examines how social and physical phenomenon interact with one another. Consequently, it can be determined that the development of spatial thinking skills and critical thinking skills are core-business for study of geography. Moreover, the preliminary results from the current research show the most difficult problem faced by teachers is to develop a set of assessment items in geography which are based on spatial thinking capabilities. Nursa'ban et al (2012) have similar results to explain that the difficulty is indicated by $41 \%$ of geography teachers who rarely use spatial thinking components in their assessment tasks, and $16 \%$ of geography teachers who never use spatial thinking components to measure levels of student achievement in geography at the beginning of SHS. Teachers found it difficult to understand how spatial thinking skills and critical thinking skills are integrated into the teaching and learning of geography. Such a condition contradicts with competency standards in the learning outcomes of the geography curriculum where the study of geography should foster the development of academic ability in learners, such as through gaining knowledge and skills to demonstrate spatial thinking and critical thinking about ways in which to overcome the problems occurring within and between physical and social environments.

Goodchild and Janelle's (2010) study illustrates the concepts of critical spatial thinking as being reflective, skeptical, or analytic. The implication is that successful application of spatial perspectives can never be memorized, it will always involve the minds of learners through active questioning and examination of assumptions, techniques, and data. Miller \& Goodchild (2014) emphasize that critical spatial thinking involves a deeper level of understanding about spatial concepts. To support this, Kim and Bednarz (2013) explain that critical spatial thinking is a constructive combination of critical thinking and spatial thinking. The second conception has been discussed by many researchers from various perspectives. The geographical context is explained by Sinton (2017) who suggests that critical spatial thinking combines spatial concepts with geographical principles to guide and inform reasoning.

The practice of critical thinking is routinely performed in a context or situation where an interpretation of geographical information, required the thinker to be either the producer or consumer of such information (Metoyer \& Bednarz, 2017). 
A critical spatial thinker understands problems, obtains solutions, and communicates effectively about processes, patterns, and outcomes in geographical contexts by applying their knowledge to scale, location, distance, and other spatial concepts, (Sharpe \& Huynh, 2015). The concept of critical spatial thinking will be elaborated in the context of factors that are relevant to the implementation of geographical learning, especially about assessment.

From the results of preliminary study conducted with 27 high school geography teachers, it is claimed that the development of factors about critical spatial thinking is needed to assess metacognition in geography. Such factors can be used as a guide for developing a comprehensive and thorough assessment of spatial thinking in metacognitive-oriented materials. Based on these needs, the researchers set out to develop a construct for the assessment of metacognition in geography through spatial thinking and critical thinking. The 2013 geography curriculum regulates the teaching and learning of geography and promotes critical thinking. The practical and detailed nature of curriculum implementation becomes the teacher's responsibility, however, the understanding exhibited by geography teachers about this matter is varied. Many geography teachers have not yet implemented the concept of critical spatial thinking into their teaching and learning practice. The results from this preliminary study also show that geography teaching still focuses on conceptual and procedural knowledge. Furthermore, geography teaching has not yet addressed factual and metacognitive critical thinking as mandated by the geography curriculum.

Astuti (2017) has operationalized the indicators of geography skills from Heffron and Down (2012) in the Indonesian curriculum. Skills are one of the outcomes of the geographical teaching and learning process, in addition to critical thinking in geography, and geographical awareness in Indonesia (MoNE, 2016). Although it is slightly different to the aforementioned study, the current study provides an alternative operational indicator for teaching and learning outcomes in geography by characterizing critical geographical thinking through a spatial approach. The implementation of these two studies can be an alternative reference for practitioners such as teachers and students in achieving learning objectives.

On the contrary, Anderson \& Krathwohl (2001) put metacognitive knowledge at the highest level of a thinking-taxonomy after factual, conceptual, and procedural knowledges. Metacognitive knowledge guides learners to elaborate their knowledge in more detailed and measurable ways. Metacognition enables a person to have a high-level ability to solve problems. Furthermore, metacognition is known as "knowledge and awareness about cognitive processes - or our thought about thinking" (Matlin, 2012). This metacognitive ability is important for the efficiency of problem solving. Aydın (2011) discusses the relationship between geography teaching and the concept of metacognition as an approach to the teaching and learning of geography through the perspective of thinking activities. A constructivist approach towards using metacognitive activities in geographical learning is recommended although unfortunately it is not yet focused on the spatial features of geography. Nevertheless, the results of this research show the relationship between stages of learning and the development of geographical skills. 
The current research investigates the construct of critical spatial thinking for metacognition in geography across SHSs where the Indonesian geography curriculum is taught. The cognitive aspects of learning geography, as mandated by the Curriculum, enable students to perform metacognitive critical thinking in their studies. This construct can be practically used by school Principals and geography teachers to evaluate the implementation of teaching and learning in geography and how to improve its quality.

\section{Methods}

The current study resulted in the identification of factors related to critical spatial thinking to assess metacognition in geography. This was achieved through a sequential mixed methods design, and the research was conducted from August 2017 to February 2019. Creswell (2011) explains the current research as a study which employs sequential exploratory methods and utilizes Research and Development ( $R$ and D). Cresswell \& Clarck (2007) state that R and D allows for the collection and analysis of qualitative and quantitative data so that the research data can be analyzed using a mixed method process which is defined as the use of "systematic study, development, and evaluation processes with an empirical basis for the creation of instructional products, tools and new or enhanced models that govern their development" (Borg \& Gall's, 2007; Mills Et al, 2011; Richey \& Klein, 2014).

The current research modifies the Research and Development model developed by Borg \& Gall (2007) and simplified ten stages into three main stages. The three stages include: a preliminary study, the design and development of the model, and an interpretation of the results of the model trials. The initial factors of assessment for critical spatial thinking as metacognition in geography were carried out in three stages: (i) the preliminary field-testing stage; (ii) the main field-testing stage; and (iii) the operational field-testing stage. Each stage validates and assesses the readability of each field-trial phase. The development stages validate each factor-of-development-phase as a separate set. The construction of instruments was obtained through the theories of critical spatial thinking in geography. A proof of construct validity uses a second order Confirmatory Factor Analysis (CFA) with the help of Lisrel.

The validation instrument utilizes a five-scale response with categories ranging from 1 (very inappropriate) to 5 (very appropriate). The item validity was determined by a recommendation from the panelist using the Aiken index formula (1996) A valid category occurred with a score of $>0.6$.

$$
V=\frac{\sum n_{i}\left(r-l_{0}\right.}{N(c-1)}
$$

Evidence of validity occurs with reference to the criteria of 'goodness of fit', to the value of $\nmid>1.96$, or the standardized loading factors $>0.3$ (Igbaria et al, 1997; Hair et al, 2010). The value of the compatibility criteria for the assessment instrument refers to namely: the Root Mean Square Error of Approximation (RMSEA) < 0.08, Probability Chi-squares >0.05, and GFI >0.90 (Garson, 2009; Hooper et al., 2008; Hair et al., 2010; and Ghozali \& Fuad, 2008) Thus, the readability of the instrument was examined for clarity around the critical spatial thinking skills in geography for metacognitive purposes. The factors of critical 
spatial thinking on metacognition were assessed by 595 participants consisting of experts and practitioners from eight SHSs across five regencies which represent Senior High Schools in Indonesia.

The assessments obtained constructive inputs about theoretical strengths from the experts and operational aspects by the practitioners. The experts examined the feasibility of the instrument, logically and theoretically, based on their field of expertise. Meanwhile, the practitioner's assessment of the instrument revealed objectivity, practicality, and the value of efficiency. There are four areas of expertise which are considered as relevant to this research: evaluation of learning, spatial thinking, geographical material, and geographical learning. The experts are lecturers in the four areas of expertise with backgrounds in geography education from six universities: Yogyakarta State University, Semarang State University, Gadjah Mada University, Indonesian Education University, Sebelas Maret University Surakarta, and Sanata Dharma University Yogyakarta. The practitioners include supervisors, school principals, geography teachers, and students (see Table 1).

Table 1

The Distribution of Research Subjects

\begin{tabular}{llllllll}
\hline \multirow{2}{*}{ No } & \multirow{2}{*}{ Research subjects } & \multicolumn{7}{l}{ Respondents / Subjects } & & \\
\cline { 3 - 7 } & Experts & $\begin{array}{l}\text { Super- } \\
\text { visors }\end{array}$ & $\begin{array}{l}\text { School } \\
\text { principals }\end{array}$ & Teachers & Students & Total \\
\hline 1 & Focus Group Discussion & 4 & 1 & 2 & 8 & 15 \\
\hline 2 & Expert Validation & 9 & & & & 9 \\
\hline 5 & Preliminary Field Testing (PFT) & 4 & 1 & 2 & 3 & 70 & 88 \\
\hline 6 & Main Field Testing (MFT) & 4 & 3 & 3 & 8 & 70 & 471 \\
\hline 7 & $\begin{array}{l}\text { Operational Field Testing } \\
\text { (OFT) }\end{array}$ & 4 & 3 & 8 & 16 & 440 & 40 \\
\hline
\end{tabular}

The results from assessment of the instrument were analyzed and respective items were revised. The final product revision was carried out as part of the final stage of obtaining a highly objective, effective, and practical review about the critical spatial thinking factors for the assessment of metacognition in geography across representative senior high schools.

\section{Findings and Results}

Three field trials were used to comprehensively assess the factors of critical spatial thinking in geography for metacognition. Factor construct is based on the results of an assessment of geography curriculum knowledge in Indonesia. The development of questions was based on the theoretical content of knowledge learning outcomes from the competency standards of learning in the Indonesian geography curriculum. The Regulation of the Minister of Education and Culture of Indonesia number 20,21, 22, 23, and 24 of 2016 states the competency standards for geography, and the standards mandates the acquisition of knowledge skills (cognitive) through critical thinking about the geographical concepts. The competency standards are aligned with the learning theories about thinking skills from Bruner (2006) and Gardner (2006). In addition, the aspects of knowledge are operationalized into various indicators by integrating the perspective of spatial thinking from Jo \& Bednarz (2010) and Anthamatten (2010). Indicators and items developed in this study are aligned with the idea 
that spatial thinking underlies the intellectual structure of the geography standards, therefore the possibility of including spatial thinking into the discipline should occur (Gersmehl \& Gersmehl, 2007; Jo \& Bednarz, 2014).

The Focus Group Discussion (FGD) has agreed to integrate the competency standards for geographical learning with two theories to produce factors of critical spatial thinking for geographical metacognition. This activity assesses and criticizes the constructs of geographical learning from the perspective of critical spatial thinking which is constructively based on a perspective of the participants' expertise. The FGD as a preliminary field-testing instrument provided the descriptions of the construct for three variables and 15 indicators as presented in Figure 1. Three variable dimensions include concept comprehension of learning, concept application, and creativity in producing ideas. The development of a conceptual dimension include the following indicators: 1) application of concepts (X1), 2) location (X2), 3) distance (X3), 4) approach (X4), 5) equation (X5), 6) disaster mitigation (X6), 7) concept map (X7), 8) interaction (X8), 9) map instrument $(X 9), 10)$ aura $(X 10), 11)$ region $(X 11), 12$ ) hierarchy $(X 12)$, 13) pattern (X13), 14) spatial association (X14), and 15) inquiry (X15).

The criteria of Aiken were used to validate the accuracy of items in assessment instrument for critical spatial thinking in geography.

Table 2

The Content Validity of Assessment Instruments of Critical Spatial Thinking Factors for the Geography Metacognition Assessment Based on the Score of the Indicators Accuracy on the Variables

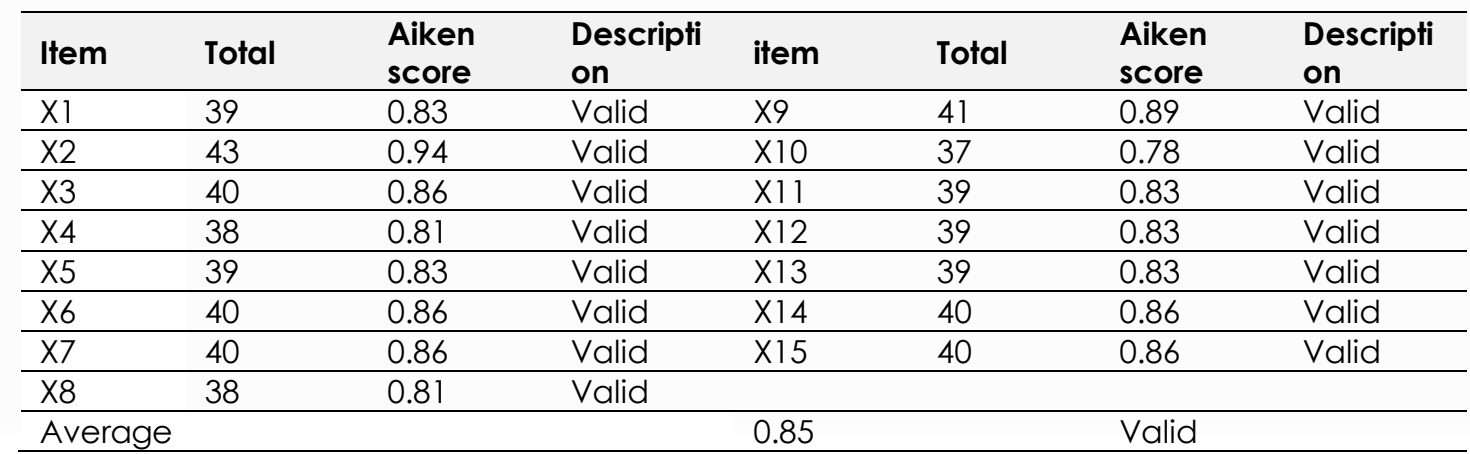

Source: The primary data on the feasibility assessment

The validation results from nine experts about the accuracy of the Critical Spatial Thinking Factors (CSTF) showed an average calculation of Aiken's validity ranges from $0.78-0.94$ with an average of 0.85 . This indicates that the factor has covered specified each variable of the learning outcomes appropriately, therefore, they are suitable for use in the assessment instrument. An overview of the pairs of indicators for each variable based on the results of the assessment using the Aiken criteria is shown in Table 3. 
Nursa'ban, M., Kumaidi, K. \& Mukminan, M. (2020). Factors of Critical Spatial Thinking for a...

Table 3

Preliminary Variables and Indicators of Critical Spatial Thinking for the Geographic Metacognitive Assessment

\begin{tabular}{|c|c|c|}
\hline No & Variables & Indicators \\
\hline & $\begin{array}{l}\text { The level of critical } \\
\text { thinking in } \\
\text { understanding the } \\
\text { geographical } \\
\text { concepts and } \\
\text { perspectives of spatial } \\
\text { thinking }\end{array}$ & $\begin{array}{l}\text { understanding the concepts of geography practically in the } \\
\text { everyday life } \\
\text { showing the absolute location of a geographical objects easily } \\
\text { determining the distance between locations of each } \\
\text { geographical object } \\
\text { using a geographical approach to explain the characteristics of } \\
\text { locations } \\
\text { identifying the similarities or differences between a certain } \\
\text { location and others } \\
\text { Understanding the theoretical mitigation efforts for natural } \\
\text { disasters. } \\
\text { designing a concept map of geographical material studied } \\
\text { describing inter-regional interactions based on their } \\
\text { advantages and disadvantages } \\
\text { understanding a geographical material using maps, charts, } \\
\text { diagrams, or other relevant media } \\
\text { explaining the influence of a region to others } \\
\text { understanding the concept of a "region" }\end{array}$ \\
\hline & $\begin{array}{l}\text { The ability to use the } \\
\text { geography concepts } \\
\text { and perspectives of } \\
\text { spatial thinking }\end{array}$ & $\begin{array}{l}\text { identifying the physical or social characteristics } \\
\text { of a region }\end{array}$ \\
\hline & $\begin{array}{l}\text { The creativity to make } \\
\text { and propose ideas to } \\
\text { describe the } \\
\text { geographical } \\
\text { conditions of the } \\
\text { environment. }\end{array}$ & $\begin{array}{l}\text { describing the geographical patterns in an area based on the } \\
\text { characteristics of the condition } \\
\text { describing the relationship between the height of a place and } \\
\text { the population density } \\
\text { understanding the scientific approach through an inquiry } \\
\text { process to understand geographical problems }\end{array}$ \\
\hline
\end{tabular}

Sources: The primary data, analysis results on the confirmatory factor analysis

Furthermore, the validity of the product is estimated by the LISREL with use of a Confirmatory Factor Analysis (CFA) technique. The CFA technique was employed by considering the initial assumption that the formulated indicators have been included in latent variables which are based on the theoretical framework and the preliminary study. 


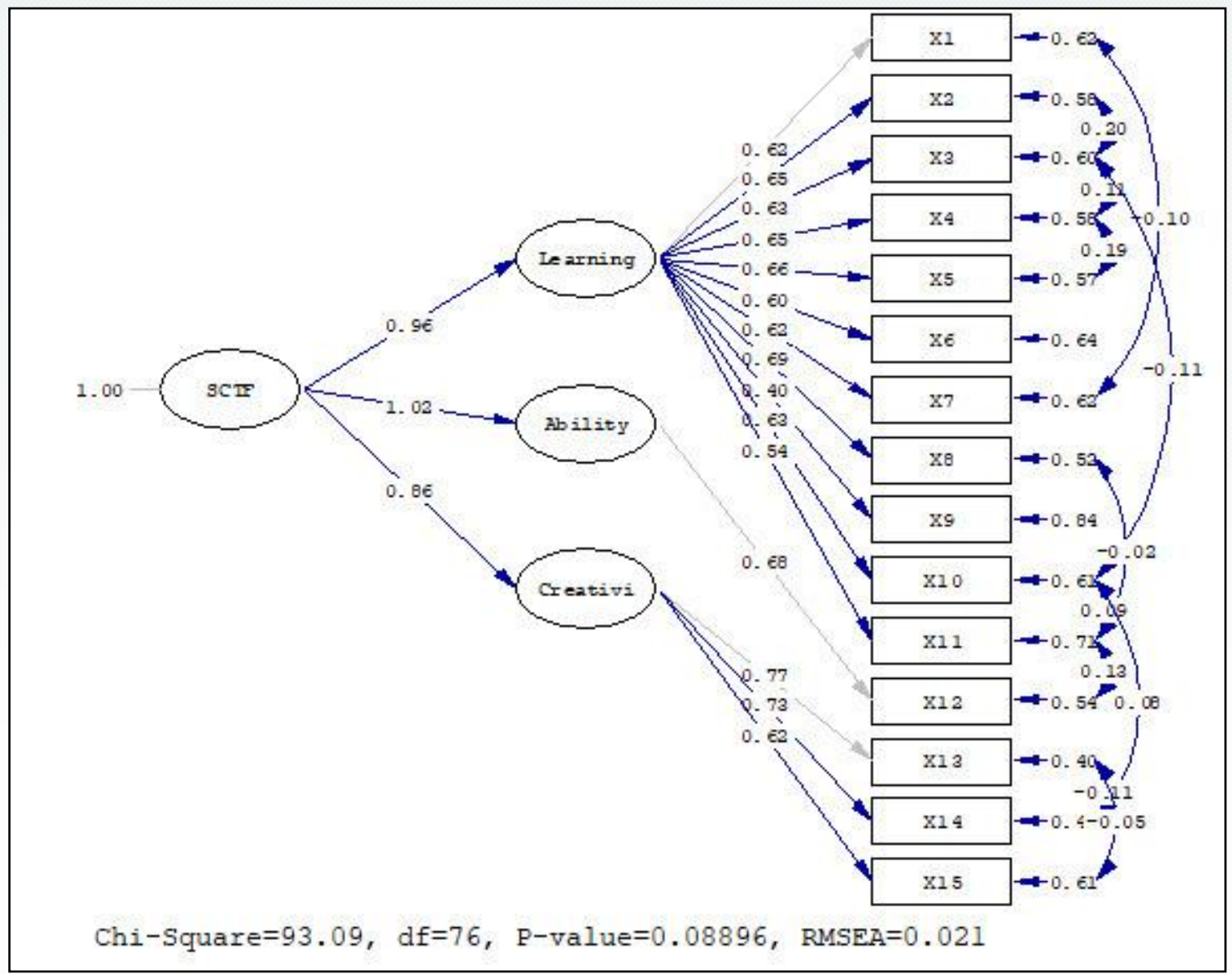

Figure 1. Result of Confirmatory Factor Analysis using LISREL to analyze the construct

Figure 1 shows the results of Confirmatory Factor Analysis (CFA) for factors of spatial critical thinking of the geography metacognition assessment. This means that the construct model had been developed and would be tested to see whether the indicators, which are grouped based on the latent variables, are consistent with the construct. The results of the CFA are T values for each coefficient $>1.96$, or the load factor $>0.3$, the Root Mean Square Error of Approximation (RMSEA) $=0.021<0.08$, Probability Chi-squares $=93,09>0.05$, and Goodness of Fit Index (GFI) $=0.95>0.90$. Estimated reliability is (a) $0.956 \geq 0.7$. Based on these results, all items have fulfilled the analysis and construct dimensions. In addition, spatial critical thinking factors have been categorized as 'fit' models.

The results presented in Table 3 and Figure 1 show the results of the second order CFA for the t-value and Standardized Loading Factor (SLF) for spatial critical thinking factor on three dimension an 15 factors proved to have a significant effect on the learning process is proven by the value of each parameter with a value of thigher than 1.96 for a significance level of $5 \%$. This means that all significant factors support the construct of the SCTF for the geography metacognition assessment model. Likewise, the yield component has subcomponents that have a significant effect. If all factors are viewed from the SLF value, they do not have a value $<0.3$. This means that all factors meet the criteria of good construct validity. The estimated reliability of the instrument at 
Nursa'ban, M., Kumaidi, K. \& Mukminan, M. (2020). Factors of Critical Spatial Thinking for a...

the operational trial stage using the help of the SPSS for Windows program shows that Cronbach's Alpha for all instruments (a) $\geq 0,956$ (above 0.7). Hair et al (2010: 688 ) states that the reliability coefficient $>0.7$ is good. Therefore, based on the construct objectives instruments, it can be said to be reliable or consistent instruments.

Table 4

The Readability of Critical Spatial Thinking Factors In the Assessment of Metacognition in Geography

\begin{tabular}{llll}
\hline \multirow{2}{*}{ No } & \multirow{2}{*}{ Readability Aspects } & \multicolumn{3}{c}{ Aiken Score } \\
\cline { 2 - 4 } & PFT & MFT & OFT \\
\hline Instruction Clarity & 0.75 & 0.78 & 0.84 \\
\hline $\begin{array}{l}\text { Clarity of instruments for critical spatial thinking factors in } \\
\text { geography }\end{array}$ & 0.61 & 0.73 & 0.77 \\
\hline $\begin{array}{l}\text { Language } \\
\text { a. Using standard Indonesian }\end{array}$ & 0.67 & 0.76 & 0.79 \\
\hline b. Using easy statement formulation & 0.72 & 0.71 & 0.81 \\
\hline c. Using clear words and phrases & 0.78 & 0.70 & 0.75 \\
\hline $\begin{array}{l}\text { Writing } \\
\text { a. The font shape and size }\end{array}$ & 0.69 & 0.76 & 0.82 \\
\hline b. Grammaticality and punctuation & 0.67 & 0.73 & 0.84 \\
\hline c. Writing format & 0.75 & 0.74 & 0.85 \\
\hline Thorough instrument assessment & 0.72 & 0.75 & 0.82 \\
\hline Average & 0.71 & 0.74 & 0.81 \\
\hline
\end{tabular}

Source: The primary data, analysis results on the readability validity. Where: PFT = Preliminary Field-testing, MFT = Main Field-testing, OFT = Operational Field-testing

Table 4 shows the Factors of critical spatial thinking to assess metacognition in geography. Assessment occurred at each stage of the field trials and the five content components were elaborated into nine table questions. Based on Aiken's formula, the readability of the critical spatial thinking factors for the assessment of metacognition in geography were in the 'very good' category because they received a score of $>0.61$.

A summary of Aiken validation results about item accuracy is given against each indicator. The items are derived from Aiken scores; an average overall accuracy of 15 items towards the indicator of 0.85 occurred within the range 0.78 to 0.94 and was therefore included in the 'valid' category. These items can possibly be an alternative reference for the critical spatial thinking dimension for assessing metacognition in geography. Nevertheless, the metacognitive domain does not show a hierarchy like Bloom's theory. Rather, cognitive abilities in learning can be revealed through the results of a multilevel process (Anderson \& Krathwohl, 2001). The factors formulated in this study have potential to be further developed and applied in the explanation of each basic competence for geography. This indicates that the developed objective items have precisely elaborated each indicator of critical spatial thinking factors for assessing metacognition in geography.

\section{Discussion}

The more frequently a teacher can connect and incorporate aspects of spatial thinking into the teaching and learning process for geography, the more the likely the teacher is to be disposed towards teaching geography in a way 
that promotes the development of spatial thinking skills. In this context, the implementation of a spatial thinking perspective into the teaching and learning of geography in schools is not considered to be an addition to the curriculum, instead it is considered to be "a missing link" in the interpretation of the curriculum.

Based on the constructs presented in Table 3 and the results of a standardized CFA, the three dimensions and 15 items are identified as factors to assess critical spatial thinking and metacognition in geography at SHSs where the 2013 Curriculum is taught. In summary, the first variable is about critical thinking levels in geographical learning, and it suggests a spatial thinking perspective can be gained by students through developing a practical understanding of the geography concepts. By emphasizing the concept of location and distance, the students will be assisted to use geographical approaches in identifying the similarities or differences that exist between one location and others. The first variable leads students to think comprehensively about a regional phenomenon by describing advantages and disadvantages of inter-regional interactions, and by explaining the superior or hierarchical influences between a region and its surrounding areas. The student's spatial and critical thinking skills are indicated by their ability to compile geographic materials and use maps, charts, diagrams.

The second variable is about the ability to apply spatial thinking perspectives to the concepts of geography, as indicated for example by the student's ability to identify the physical or social characteristics of a region. The third variable is about creativity in proposing ideas. This variable is demonstrated by student capability in describing geographical patterns of an area based on the characteristics of its condition. In addition, the third variable is also measured by student ability to describe the relationship between the height of a place and density of its population, as well as by the ability of students to understand the stages of a scientific inquiry approach through which geographical problems are identified. The paradigm in both variables are substantially relevant to the work of Kerski (2015), Bednarz et al (2013), Schell et al (2013), Stoltman (2012), Dewey (2008) and Nagel (2008) who stated that the future of teaching and learning in geography will focus on systems-thinking, spatial thinking and critical thinking through the use of geospatial technology to solve social and environmental problems about sustainability. Mohan et al. (2015) added that geography is a complex scientific discipline with a focus on characteristics, relationships, and spatial patterns of human and natural activities. Geography teaches about culture, geopolitics, natural systems, the use and distribution of resources, and the mapping of spatial data to better understand the world.

Bednarz et al (2013) predicts that the geographical learning load in the $21^{\text {st }}$ century will be: (1) emphasizing on a geographical perspective (spatial thinking and ecological interactions in the world); (2) concepts as the main core of learning (Location, Place, Interaction of Human Environment, Movement and Region); and (3) emphasizing core skills (asking geographical questions, obtaining geographic information, presenting and analyzing geographic information, and developing and testing geographical generalizations). Heffron and Downs (2012) adds that space and place are crucial dimensions of geography so an understanding about spatial patterns and processes is very important to appreciate how humans live on earth. 
Creswell (2006) shows that one of the most obvious absences in the spatial approach towards the teaching and learning of geography is a sense of values and meaning that can be embedded in mobility; thus, spatial construction is needed. The National Research Council (2006) pioneered the idea that spatial thinking underlies the intellectual structure of the geography standards, and in doing so demonstrated the possibility and power of instilling spatial thinking into a discipline. Jo and Bednarz (2014) emphasize that the teaching of geography is actually about the teaching of spatial thinking skills.

The results from this study about the development of critical thinking skills were interpreted as indicators to understand, apply, and analyze factual, conceptual, and procedural knowledges of objects in geography. Irwanto et.al (2018) published the results of research on students' critical thinking skills in Elementary School Teacher of Education (PGSD) through a Process-Oriented Guided-Inquiry Learning approach (POGIL). A critical thinking essay test (CTET) includes five indicators to be used in the study: (i) elementary clarification; (ii) a bases for decision-making; (iii) an inference; (iv) advanced clarification; and (v) supposition and integration.

The critical thinking content is similar to the perspective of spatial thinking in this study. The results of geographical learning on cognitive aspects are presented as an ability to recognize the concept of space, use of representationtools, and use of cognitive processes. Critical thinking in this study was different to the work of Irwanto et. al (2018). The first difference occurs in terms of critical thinking with basic geographical competencies. The second difference occurs in the purpose of spatial thinking activities.

Akbay et al., (2018) compiled a critical thinking component with six of the previous seven components. Kökdemir (2003) claims that six components are more relevant to the 51 factors which were analyzed by a Turkish version using a 6-point Likert scale item with an internal consistency index of 0.88 . The six critical thinking components offered by Akbay et al., (2018) comprise analyticity, openmindedness, curiosity (inquisitiveness), systematic thoughts, self-confidence, and truth-seeking. The six components are the same in this study where critical thinking begins with analytical activities in the study of geographical knowledge. The second equation is the process of Confirmatory Factor Analysis (CFA) to reconstruct the concept of critical thinking so it becomes suitable for its purpose. The difference between Akbay et al., (2018) research and the current study is the description of the components and the successful compilation of factors. The current research develops the concept of critical thinking in connection to the learning outcomes for knowledge in the geography curriculum.

The National Research Council (2006) states that integration and infusion of spatial thinking into the teaching and learning of geography, can help to achieve existing curricular objectives. Spatial thinking is another lever to enable students to achieve deeper understanding of subjects across the curriculum. This statement explains that the purpose of integrating spatial thinking in learning is to foster the development of skills in learners, such as: (1) developing a habit of spatial thinking, (2) practicing spatial thinking in the context of known information, and (3) trying to be critical as a result of engaging with spatial thinking processes. 
The three-dimensional factors of SCTF, arising as a result of the study, are aligned with the geography curriculum content in Indonesia. A substantial amount of material in geography is taught through the application of spatial representations which are formulated from the relationship between systems of human and environmental interactions across three dimensions. The geographical perspective on the dynamics of the physical environment and the community environment will be seen from the spatial integration and interdependence of space between places and scale. This perspective can be manifested in real or abstract forms (and or representations) either visually, verbally, mathematically, or digitally. It can also be represented in a (cognitive) mindset.

In the current study, the geographical learning outcomes of Critical Spatial Thinking puts spatial thinking as the main characteristic of geography, and it is interpreted as a way equip students to gain higher levels of academic achievement. The intellectual structure of the spatial thinking aspects of the geography standards are implemented in the context of achieving core competencies, as stated in the graduates' competency standards and geography competency standards. Geography in schools with its perspective of spatial thinking, is not seen to be an addition to the curriculum, rather it is seen to be "a missing link" in the way core geographical content is interpreted. Learning outcomes change as a result of the learning process or after a new learning experience (Sujana, 2009; Hamalik, 2013; and Winkel, 2009). From the current study, the dimensions and factors related to the achievement of learning outcomes in geography are in support the work of produced by Beneker and Schee (2015). They explain that learning outcomes in geography education throughout the world have different points of view and focus. The substance of the SCTF factor support the work of Heffron (2012) in that the standard of geography knowledge represents four main competencies: 1). Doing geography: the geographic lens on the world; 2) Looking at the world in multiple ways: geographic perspectives; 3) Knowing about the world: geographic content knowledge; and 4) Asking and answering geographic questions about the world: geographic skills.

Hopkin (2011) concluded that knowledge obtained from geography was able to analyze differences and uniqueness in each of its phenomena. Hopkin (2011) emphasized two things about geographical knowledge: that knowledge as an important part of finding out about the world through reasoned inquiry (otherwise known as enlightenment ideals); and the idea of knowledge as power, which refers to the idea that people who are knowledgeable and educated are often the same. Goodchild \& Janelle (2010) explain that along with the development of Science and Technology, the integration of geographical knowledge into the Social Sciences and Humanities require the development and use of critical spatial thinking skills. An important strength for such integration is the ability to think spatially.

Various definitions from the literature suggest that geography is a scientific discipline where spatial thinking acts as a connecting device between phenomena of the physical environment and social dynamics. Legates (2005) stated that a number of studies on the concentration of Social Science courses (including geography) have used Geographic Information Systems to interpret 
spatial information in their fields of study. Gersmehl in Anthamatten (2010) composed and proposed the concept of spatial thinking, designed for geographical learning at all educational levels. Meanwhile, Lee and Bednarz (2012) concluded that learning from Geographical Information Systems is more likely to occur when lessons are explicitly designed to require students to perform spatial tasks, that is, to use one or more components of spatial thinking. Lee and Bednarz (2012) also added that educators are required to develop learning designs that enable students to develop several abilities in spatial aspects.

Finally, the three dimensions are elaborated into 15 factors of critical thinking related to geographical learning. There are three aspects of knowledge in the curriculum for geography subjects: (1) levels of understanding, applying, and analyzing factual, conceptual, procedural, and metacognitive knowledges about the object of geographical study; (2) an ability to overcome problems related to the study of geographical objects; and (3) developing creativity in creating and proposing ideas to renew the physical environment and social environment as resources. The three aspects of critical spatial thinking are detailed, and they are operationalized through a set of processes related to understanding concepts as terminology in general, understanding such terminology in detail, presenting models of knowledge, and presenting information that is systematically and functionally interconnected. It describes a series of steps to obtain measurable knowledge, awaken cognitive abilities in solving problems, and stimulate students to overcome problems related to the object of geographical study and finally, encourage creativity in creating and proposing ideas to renew the condition of the surroundings. These three indicators form the basis for developing the learning outcomes of geography and critical spatial thinking. The critical spatial thinking perspective from Jo \& Bednarz (2010) and Gersmehl (2007) served as the indicators and operational aspects of critical thinking

\section{Conclusion}

This study has produced factors of critical spatial thinking for a geography metacognition test through the use of three variable dimensions: concept comprehension, concept application, and creativity in producing ideas. Indicators from the development of the conceptual dimension include: 1) application of concepts, 2) location, 3) distance, 4) approach, 5) equation, 6) disaster mitigation, 7) concept map, 8) interaction, 9) map instrument, 10 ) aura, 11 ) region, 12) hierarchy, 13) pattern, 14) spatial association, and 15) inquiry. The concept application occurs through an understanding about the concept hierarchy related to phenomena from physical or social geography based on either physical or social aspects of an observed region. The third dimension about creativity in producing ideas, refers to the ability to create patterns, spatial associations, and inquiries.

\section{Acknowledgements}

The author would like to thank the Ministry of Research Technology and Higher Education in the Republic of Indonesia and Yogyakarta State University who have fully supported this work which therefore facilitates the publication of this article. 


\section{References}

Aiken, L. R. (1996). Rating Scales and Checklist: Evaluation Behavior Personality, and Attitude. New York: John Wiley \& Sons Inc.

Akbay T., Akbay, L., Gülsoy, V. G. B. (2018). Causal effect of epistemological beliefs and metacognition on critical thinking disposition. Mehmet Akif Ersoy Üniversitesi Eğitim Fakültesi Dergisi. Vol: 45, 88-104. DOI: 10.21764/maevefd.349581.

Anderson, L.W. \& Krathwohl, D. R. (2001) Taxonomy for learning teaching and assessing: A revision of Bloom 's taxonomy of educational objectives. London; Longman Press.

Anthamatten, P. (2010). Spatial thinking concepts in early grade-level geography standards. Journal of Geography. Vol:109. 169-180. DOI. 10.1080/00221341.2010.498898

Astuti, Y. (2017). Assessment concept of geographical skills on senior high school in Indonesia. American Journal of Educational Research, Vol: 5(7), 879-886. DOI: 10.12691/education-5-8-7

Aydın, F. (2011). Geography teaching and metacognition. Educational Research and Reviews Vol: 6 (3). 274-278. Retrieved from: https://academicjournals.org/journal /ERR/article-full-text-pdf/B61F68D488

Bednarz, S.W. \& Bednarz, R.S. (2008). Spatial thinking: The key to success in using geospatial technologies in the social studies classroom. (In A.J. Milson \& M. Alibandri (Eds). Digital geography: Geo-spatial technologies in the social studies classroom (pp.249-270), New York: Information Age Publishing.

Bednarz, S.W., Heffron, S., \& Huynh, N.T. (Eds.). (2013). A road map for 21 st century geography education: Geography education research (A report from the Geography Education Research Committee of the Road Map for 21 st Century Geography Education Project). Washington, DC: Association of American Geographers.

Beneker, T. \& Schee, J.V.D. (2015). Future geographies and geography education. International Research in Geographical and Environmental Education. Vol: 24(4), 287-293. DOI: 10.1080/10382046. 2015.1086106.

Bonnet, Alastair. (2008). What is geography? Los Angeles: Sage Publication.

Borg, W. R., \& Gall, M. D. (2007). Educational research: An introduction (8th Ed.). New York, NY: Longman.

Branch, Benjamin D. (2014). Information literacy beyond the library. Libraries and spatial literacy: Toward Next-Generation Education College \& Undergraduate Libraries, Vol: 21.109-114. DOI: 10.1080/10691316.2014.877745

Bruner J.S. (2006). In search of pedagogy volume 1: (the selected works of Jerome S. Bruner). London and New York: Routledge

Creswell, T. (2006). On the move: Mobility in the modern western world. New York: Routledge.

Creswell, T. (2011). Educational research: planning, conducting, and evaluating quantitative and qualitative research (Fourth edition). Boston: Pearson Education, Inc.

Dewey, D. I. (2008). Teaching experiential learning in geography: Lessons from planning, Journal of Geography, Vol:107 (4-5), 167-174, DOI: 10.1080/ 0022134 0802511348

Gardner, H. (2006). The development and education of the mind. ((The selected works of Howard Gardner). London and New York: Routledge 
Nursa'ban, M., Kumaidi, K. \& Mukminan, M. (2020). Factors of Critical Spatial Thinking for a...

Gardner, H. (2011). Frames of mind: The theory of multiple intelligences. New York: Basic Books

Garson, G. D. (2009). Logistic regression. Retrieved from: http://faculty.chass.ncsu.edu/ garson/PA765/logistic.htm

Gersmehl, P. J. \& Gersmehl, C.A. (2007). Spatial thinking by young children: neurologic evidence for early development and "educability". Journal of Geography. Vol: 106: 181-191. DOI: 10.1080/ 00221340701809108.

Ghozali, I. \& Fuad (2008) Structural equation modelling. Semarang: BP Undip.

Gold, A. U., Pendergast, P. M., Ormand, C. J., Budd, D. A., Stempien, J. A., Mueller, K. J., \& Kravitz, K. A. (2018). Improving spatial thinking skills among undergraduate geology students through short online training exercises. International Journal of Science Education. Vol: 14(2), 668-683. DOI: 10.1080/09500693.2018.1525621.

Golledge, R., Meredith, M., \& Battersby, S. (2008). A conceptual framework for facilitating geospatial thinking. Annals of the Association of American Geographers, Vol: 98 (2) 2008. 285-308. DOI: 10.1080/00045600701851093

Goodchild, M. F. \& Janelle, D.G. (2010). Toward critical spatial thinking in the social sciences and humanities. GeoJournal. Vol: 75. 3-13. DOl:10.1007/s10708-010-93403.

Hair, J.F., Anderson, R.E., Tatham, R.L., \& Black, W.C., (2010). Multivariate data analysis, fifth edition. New Jersey: Prentice-Hall International, Inc.

Hamalik, O. (2013). Curriculum and learning (Kurikulum \& pembelajaran) Jakarta: Bumi Aksara

Hanifah, M., Mohmadisa, H., Yazid, S, Nasir, N., Balkhis, N., S. (2019). Professional and pedagogical competencies of form six geography teachers in malaysia. Review of International Geographical Education Online (RIGEO), 9 (2), 304-318. Retrieved from http://www.rigeo.org/vol9no2/Number2Summer/RIGEO-V9-N2-3.pdf

Heffron, S. G. \& Down, R. (2012). Geography for life: National geography standards. Washington: National Council for Geographic Education

Heffron, S. G. (2012) GFL2! The updated geography for life: National geography standards, second edition. The Geography Teacher. Vol: 9 (2): 43-48. DOI: $10.1080 / 19338341.2012 .679889$

Hooper, D. Couglan, J., \& Mullen, M.R. (2008). Structural equation modelling: guidelines for determining model fit. Electronic Journal of Bussines Reserach Methods. Vol: 6 (1), 53-60. Retrieved from: online at www.ejbrm.com

Hopkin, J. (2011). Geography in progress. Geography. Vol: 96 Part 3, 116-123. Retrieved from https://www.geography.org.uk/Journal-Issue/ad708293-31b5-48e2-9beabdcc7124cdd6.

Igbaria, M., Zinatelli, N., Cragg, P., \& Cavaye, A. L. (1997). Personal computing acceptance factors in small firms: a structural equation model. MIS quarterly. Vol: 21 (3). Retrieved from: https://www.jstor.org/stable/249498

Irwanto, S., A. D., Rohaeti, E., \& Prodjosantoso, A. K. (2018). Promoting critical thinking and problem-solving skills of preservice elementary teachers through Process-Oriented Guided-Inquiry Learning (POGIL). International Journal of Instruction. Vol: 11 (4), $777-$ 794. DOI: 10.12973/iji.2018.11449a

Jo, I. \& Bednarz, S. W. (2010). Evaluating geography textbook questions from a spatial perspective: Using concepts of space, tools of representation, and cognitive processes to evaluate spatiality. Journal of Geography, Vol: 108: 4-13. DOI: 10.1080/00221340902758401. 
Jo, I. \& Bednarz, S. W. (2014). Dispositions toward teaching spatial thinking through geography: Conceptualization and an exemplar assessment. Journal of Geography. Vol: 113(5). 198-207. DOI: 10.1080/00221341.2014.881409

Kerski, J., (2015). Teaching geography in the twenty-first century: New Tools Are Available to Teach Geography in More Engaging, Dynamic, and Effective Ways. Retrieved from: https://blogs.esri.com/esri/esri-insider/2015/01/26/teaching-geography-inthe-twenty-first-century/

Kim, M. \& Bednarz, R. (2013) Effects of a GIS course on self-assessment of Spatial Habits of Mind (SHOM). Journal of Geography. Vol: 112 (4), 165-177, DOI: $10.1080 / 00221341.2012 .684356$

Kökdemir, D. (2003). Decision making and problem solving in cases of uncertainty (Belirsizlik durumlarında karar verme ve problem çözme). Unpublished doctoral dissertation, Ankara University, Institute of Social Sciences, Ankara.

Kozikoğlu, ì. (2019). Investigating critical thinking in prospective teachers: Metacognitive skills, problem solving skills and academic self-efficacy. Journal of Social Studies Education Research. Vol: 10 (2), 111-130. Retrieved from: https://www.jsser.org/index.php/jsser/article/view/362/0

Lambert, D. \& Morgan, J. (2010). Teaching geography (11-18): A conceptual approach. New York: Open University Press.

Lee, J. \& Bednarz, R. (2012). Components of spatial thinking: Evidence from a spatial thinking ability test. Journal of Geography. Vol: 111: 15-26. DOI: 10.1080/00221341.2011.583262

Legates, R. (2005). Teaching spatially integrated research methods. In the 25th Annual ESRI International Users Group Conference, city, state.

Matlin, Margaret W. (2012). Cognition (8th Edition). Philadelphia: Wiley

Metoyer, S., \& Bednarz, R. (2017). Spatial thinking assists geographic thinking: evidence from a study exploring the effects of geospatial technology. Journal of Geography. Vol: 116 (1), 20-33. Retrieved from: https://doi.org/10.1080/ 00221341. 2016.1175495

Miller, H.J. and M.F. Goodchild. (2014). Data-driven geography, GeoJournal, Vol: 80 (4). 449-461. DOI: 10.1007/s10708-014-9602-6.

Mills, G. E., Gay, L. R., \& Airasian, P. (2011). Educational research: Competencies for analysis and applications. Boston: Pearson.

Mohan, L., Mohan, A., \& Uttal, D. (2015). Research on thinking and learning with maps and geospatial technologies. In Solem, M., Huynh, N. T., \& Boehm, R. (eds). Geo progressions. Learning progressions for maps, geospatial technology, and spatial thinking. pp. 9-21. American Association of Geographer. Retrieved from: http://www.ncrge.org/

MONE (Ministry of National Education of Indonesia). (2016). Regulation of ministry of national education number 23/2006 of process standard of basic and middle education (Peraturan menteri pendidikan nasional nomor 23 tahun 2016 tentang standar proses pendidikan dasar dan menengah).

Nagel, P. (2008). Geography: The essential skill for the 21st century. Social Education. Vol: 72(7), 354-358 Retrieved from: https:// www.socialstudies.org/system/files /publications /articles/se_7207354.pdf.

National Research Council. (2006). Learning to think spatially GIS as a support system in the K-12 curriculum. Washington, DC: National Academy Press.

Newcombe, N. S. \& Shipley, T. F. (2015). Thinking about spatial thinking: New typology, new assessments. New York: Springer 
Nursa'ban, M., Kumaidi, K. \& Mukminan, M. (2020). Factors of Critical Spatial Thinking for a...

Nursa'ban, M., Suparmini, \& Sriadi. (2012). Evaluation of pedagogic competency of sma geography teacher of bantul regency. (Evaluasi kompetensi pedagogik guru geografi SMA kabupaten Bantul.) Socia. Vol: 11(2), 165-182. DOI: 10.21831/socia.v1 1i02.3607

Prasetyo, Ketut. (2013). Level of knowledge of the territory of the unitary state of the republic of Indonesia in the younger generation (Case study of fis unesa geography education student 2012). (Tingkat pengetahuan wilayah negara kesatuan republik Indonesia pada generasi muda (studi kasus pada mahasiswa pendidikan geografi FIS UNESA tahun 2012). Proceeding of The Annual Scientific Meeting of Indonesia Geography Association (IGI) to XVI 2013 in Banjarmasin. ISBN: 978-602-1322-00-0.

Richey, R., \& Klein, J. D. (2014). Design and development research: Methods, strategies, and issues. London: Routledge

Schell, Emily M., Roth Kathleen J., Mohan Audrey. (2013). Road map for 21 st century geography education project instructional materials and professional development recommendations and guidelines for instructional materials and professional development in geography education. London: Routledge.

Sharpe, B. \& Hyunh, N.T. (2015). A review of geospatial thinking assessment in high school. in Solary, O.M. (Eds) Geospatial technologies and geography education. advances in geographical and environmental sciences. P. 169-180. Japan: Springer. https://doi.org/10.1007/978-4-431.55519-3_14.

Sinton, D.S. 2017. Critical spatial thinking. In the International Encyclopedia of Geography. Edited by Douglas Richardson, Noel Castree, Michael F. Goodchild, Audrey Kobayashi, Weidong Liu, and Richard A. Marston. John Wiley \& Sons, Ltd. DOI: 10.1002/9781118786352.wbieg0706

Stoltman, J. (2012). Perspective on geographical education in the 21 st century. Journal of Research and Didactics in Geography (J-READING), Vol: 0(1). 17-24. DOI: $10.4458 / 1005-03$

Sujana, N. (2009). Learning outcomes assessment (Penilaian hasil belajar). Bandung: Rossda Karya

Swasono, S. E. (2014). Geography awareness: Maritime state Indonesia and ASEAN (Kesadaran geografi: keindonesiaan negara maritim dan ASEAN). Academic Oration: Annual meeting of Indonesian Geography Association in Yogyakarta, 15 November 2014.

Uttal, D. H., \& Cohen, C. A. (2012). Spatial thinking and STEM education: When, why and how.'. Psychology of Learning and Motivation, Vol: 57, 147-181. DOI: 10.1016/B9780-12-394293-7.00004-2

Uttal, D.H., D.I. Miller \& N.S. Newcombe. (2013). Exploring and enhancing spatial thinking: Links to achievement in science, technology, engineering, and mathematics? Current Directions in Psychological Science, Vol: 22 (5), 367-373. DOI: $10.1177 / 0963721413484756$

Winkel, W.S. (2009) Instructional Psychology (Psikologi Pengajaran). Yogyakarta: Media Abadi.

\section{Biographical Statements}

Muhammad NURSA'BAN is an Associate Professor, at the Department of Geography Education, Faculty of Social Sciences, Yogyakarta State University since 2005. His expertise is geography educational evaluation. He is the chairperson of the faculty of quality assurance, and the secretary of the university's audit center. He is concerned with 
the efforts to develop the quality of teachers, educational evaluation, and learning innovation.

Kumaidi KUMAIDI is a Professor of educational measurement and assessment at the Faculty of Psychology, Muhammadiyah University of Surakarta. His area of expertise includes educational measurement and assessment. He is an educational testing consultant at the Indonesian Ministry of Education

Mukminan MUKMINAN is a Professor of geography learning technology at the Department of Geography Education, Faculty of Social Sciences, Yogyakarta State University. He is the head of the geography education master's program at YSU. He is a member of the Indonesian National Education Standards Board. His area of expertise is geography education technology, and social studies. 